\title{
The forage value of poplars and willows
}

\author{
P.D. KEMP ${ }^{1}$, A.D. MACKAY ${ }^{2}$, L.A. MATHESON ${ }^{1}$ and M.E. TIMMINS ${ }^{1}$ \\ ${ }^{1}$ Institute of Natural Resources, Massey University, Palmerston North \\ ${ }^{2}$ AgResearch Grasslands, Palmerston North \\ ${ }^{1}$ P.Kemp@massey.ac.nz
}

\begin{abstract}
Poplars and willows planted on farms for soil conservation and shelter are also potential sources of supplementary forage. The objective of this paper is to provide information that assists in the estimation of the value of poplar and willow forage. The quantity of forage in trees and branches was measured and non-destructive methods for estimating forage yield were evaluated. The edible forage dry matter (DM) of 5-10-year-old trees ranged from $2-22 \mathrm{~kg} \mathrm{DM} /$ tree. The edible forage yield of poplar and willow branches with a basal diameter (BD) up to $100 \mathrm{~mm}$ was shown to be estimated from $\mathrm{kg} \mathrm{DM}=0.04 \mathrm{BD}-0.6$. The nutritive values of poplars and willows were found to be similar, but the concentration of condensed tannins was usually higher in willows. Tree bark was found to have sufficient nutritive value to be stripped from trees for its feed value by livestock. Cattle were observed to be able to browse willows to a height of $2 \mathrm{~m}$ and to eat stems with a diameter from 2.7 to $7 \mathrm{~mm}$.
\end{abstract}

Keywords: browse estimation, condensed tannins, nutritive value, poplar, supplements, willow

\section{Introduction}

Poplars and willows have been extensively planted in New Zealand to control soil erosion on hill pastoral farms (Wilkinson 1999). The leaves and twigs of poplars and willows are often used in dry summers as supplementary forage. Although the poplars and willows are potentially a major forage resource on many hill farms there is scant information available on their forage value (Wall et al. 1997). This limits the use and management of this resource. To fully use poplar and willow forage, farmers need to know the quantity of forage available in a tree, the nutritive value of the forage, the growth rate of livestock feeding on the forage, and the consequences of different harvest methods to forage utilisation and tree growth. The objectives of this paper are to contribute to the information required by farmers by providing: 1) methods for estimating the quantity of poplar and willow forage in trees and branches, and 2) information on the nutritive value of poplar and willow forage and the levels of utilisation by cattle browsing willows.

\section{Methods}

Aspects of the production, nutritive value and utilisation of forage in poplars and willows were examined in four experiments.

Experiment 1. In the Wairarapa, three trees $(5,7 \&$ 10 years old) each of Veronese poplar (Populus deltoides $\mathrm{x}$ nigra) and Tangoio willow (Salix matsudana $\mathrm{x} a l b a$ ) were felled after the measurement of diameter at breast height (DBH), tree height, green canopy length and maximum canopy width. Then all leaves and edible stems (defined as less than or equal to $5 \mathrm{~mm}$ diameter) were removed, oven dried at $70^{\circ} \mathrm{C}$ and weighed. Trunk cross-sectional area (TCA) was calculated at breast height $(1.4 \mathrm{~m})$, and canopy surface area (CSA) was calculated by assuming the tree canopies were best represented as vertical ellipsoids (Karlik \& Winer 1999). CSA was used as a non-destructive estimate of edible dry matter.

In Experiment 2, the dimensions of 50 trees each of Tangoio willow and Veronese poplar in a range of environments in the Wairarapa were non-destructively measured as in Experiment 1. A branch from the lowest whorl was cut as close as possible to the trunk from each tree, the basal stem diameter measured and all leaves and edible stems $(<5 \mathrm{~mm}$ diameter) removed and weighed. A relationship between branch diameter and edible DM was developed.

The nutritive value of the bark of Tangoio willow and Veronese poplar was assessed. A bark sample measuring $150 \mathrm{~mm} \times 50 \mathrm{~mm}$ was taken from eight individual trees measured in Experiment 2. The eight samples of bark were from Tangoio and Veronese trees aged 5 and 10 years at two sites. The bark was stored frozen $\left(-25^{\circ} \mathrm{C}\right)$, freeze-dried, ground with a Wiley mill to pass through a 1-mm-aperture sieve and then analysed for nitrogen content, digestibility, soluble carbohydrates, ash and condensed tannins.

In Experiment 3, the nutritive value (digestibility, crude protein, neutral detergent fibre, ash, metabolisable energy, total condensed tannins) of the leaves plus edible stems ( $<5 \mathrm{~mm}$ diameter) of seven poplar cultivars 
and three willow cultivars was measured in summer $(3$ March 2000) on coppiced trees at Akura Nursery near Masterton. Three branches per tree were sub-sampled from three trees of each cultivar and the material pooled before being ground and analysed.

In Experiment 4, the preference and grazing behaviour of several classes of cattle browsing Tangoio and Kinuyanagi willow trees were observed and their utilisation of the edible forage on the trees estimated at two sites (Massey University, Palmerston North and Ballantrae, AgResearch Hill Research Station, near Woodville). Tagasaste (Chamaecytisus proliferus subsp. proliferus var. palmensis) was also present at the Massey University site. The cattle had all previously browsed trees, but the cows at the Massey University site had less experience of browsing than the cows at the Ballantrae site. Approximately 20 animals per day were used to browse the trees at each site for 6 days.

\section{Results}

\section{Estimation of forage yield}

The forage yields and tree dimensions of Tangoio and Veronese were similar for trees of the same age (Table 1), but the limited data were insufficient to identify the relationship between DBH and forage yield. However, Figure 1 shows that for the Veronese trees measured in Experiment 2, the relationship between trunk cross-sectional area and canopy surface area was curvilinear $\left(r^{2}=0.9\right)$. For Tangoio (data not presented) the relationship was similar $\left(r^{2}=0.8\right)$. Trunk cross-sectional area increased faster than canopy surface area (Figure 1). That is, the quantity of forage (leaves plus $<5 \mathrm{~mm}$ stems) per tree, assuming CSA is an indirect measure of forage DM (Table 1), was not increased in direct proportion to the increased trunk diameter and cross-sectional area as the tree aged (Figure 1).

Basal diameter of the lowest branch of Tangoio $\left(r^{2}=\right.$ $0.68)$ and of Veronese $\left(r^{2}=0.80\right)$ was a better predictor of the forage yield of the branch than branch length $\left(\mathrm{r}^{2}=\right.$ 0.31 and 0.47 ), or a combination of basal diameter and branch length. Branch length ranged from 1.5-4.3 m for Tangoio and from 1.3-3.8 m for Veronese. Over the range of branch basal diameters measured, the forage yield of the branch was best estimated by a linear than a curvilinear function. On average $52 \%$ of the branch dry matter was forage. The equations relating forage yield of a branch to its basal diameter (BD) are given below:

Tangoio: Forage yield $(\mathrm{kg} \mathrm{DM})=0.041 \mathrm{BD}-0.662$, for BD 19-48 mm. $(\mathrm{n}=50)$.

Figure 1 The curvilinear relationship between canopy surface area (used as an indirect measure of forage dry matter) and the cross-sectional area of the tree trunks of 50 Veronese poplars in a range of environments in the Wairarapa.

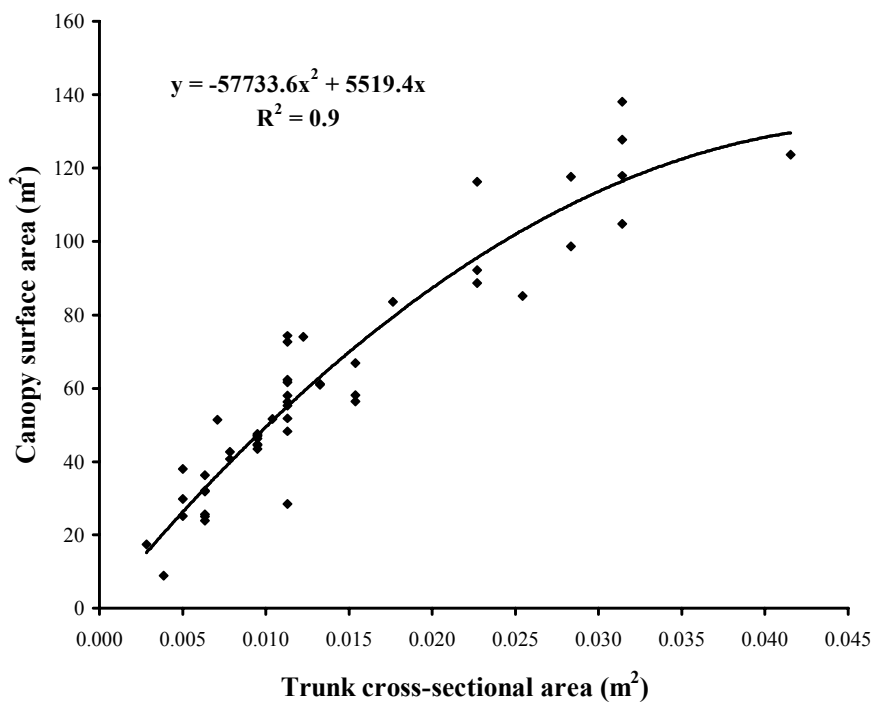

Table 1 Edible forage yield ( $\mathrm{kg}$ DM/tree) and dimensions of Tangoio willow and Veronese poplar trees of different ages in the Wairarapa.

\begin{tabular}{|c|c|c|c|c|c|c|c|}
\hline Cultivar & $\begin{array}{c}\text { Age } \\
\text { (years) }\end{array}$ & $\begin{array}{l}\text { Forage DM }{ }^{1} \\
(\mathrm{~kg})\end{array}$ & $\begin{array}{c}\text { DBH } \\
(\mathrm{m})\end{array}$ & $\begin{array}{l}\text { Canopy width } \\
\text { (m) }\end{array}$ & $\begin{array}{l}\text { Canopy length } \\
\text { (m) }\end{array}$ & $\begin{array}{l}\text { TCA } \\
\left(\mathrm{m}^{2}\right)\end{array}$ & $\begin{array}{l}\text { CSA } \\
\left(\mathrm{m}^{2}\right)\end{array}$ \\
\hline \multicolumn{8}{|c|}{ Willow } \\
\hline Tangoio & 5 & 3.0 & 0.09 & 2.3 & 3.71 & 0.006 & 23.1 \\
\hline Tangoio & 7 & 9.5 & 0.14 & 3.4 & 7.02 & 0.015 & 63.8 \\
\hline Tangoio & 10 & 22.4 & 0.20 & 6.3 & 8.34 & 0.031 & 152.3 \\
\hline \multicolumn{8}{|c|}{ Poplar } \\
\hline Veronese & 5 & 1.6 & 0.07 & 2.2 & 3.03 & 0.004 & 19.2 \\
\hline Veronese & 7 & 7.5 & 0.14 & 3.0 & 6.94 & 0.015 & 54.9 \\
\hline Veronese & 10 & 18.0 & 0.21 & 4.2 & 12.73 & 0.036 & 137.5 \\
\hline
\end{tabular}

${ }^{1} \mathrm{DM}$ - dry matter, $\mathrm{BH}$ - diameter at breast height, TCA - trunk cross-sectional area, CSA - canopy surface area 
Veronese: Forage yield $(\mathrm{kg} \mathrm{DM})=0.044 \mathrm{BD}-0.597$, for BD $14-48 \mathrm{~mm}$. $(\mathrm{n}=50)$.

\section{Forage quality}

The percentage leaf and the nutritive value of poplar and willow forage were similar (Table 2). There were no significant differences in digestibility, crude protein and metabolisable energy between cultivars $(\mathrm{P}=0.21$, $0.21,0.10)$. However, the percentage of total condensed tannins (CT) in the forage was significantly greater in willows than poplars, and differed between their cultivars $(\mathrm{P}=0.0001)$.

Tangoio bark had significantly higher DMD ( $\mathrm{P}=$ $0.0187)$, protein concentration $(\mathrm{P}=0.0149)$, ash concentration $(\mathrm{P}=0.0125)$, and total condensed tannins concentration $(\mathrm{P}=0.0002)$ than Veronese bark (Table 3$)$. Soluble carbohydrate levels were only assessed for one sample of 5-year-old bark from each of Tangoio and Veronese. The willow bark had a readily fermentable carbohydrate concentration of $15.4 \%$ (10.1\% reducing sugars, $5.3 \%$ pectin) and the poplar bark was $16.2 \%$ (11.2\% reducing sugars, $5.0 \%$ pectin). Veronese had a significantly higher concentration of NDF than Tangoio ( $\mathrm{P}=0.0482)$.

There were no significant differences in the nutritive value of the bark of 5-year-old and 10-year-old trees (Table 3).

\section{Forage utilisation}

Browsing height for cattle was from 1.6-2.2 m (Tables 4 and 5). From this height the cattle browsed $0.7-2.4 \mathrm{~kg} \mathrm{DM} /$ tree depending on willow cultivar and the coppiced height of the tree. Utilisation of tree forage was higher for Kinuyanagi than for Tangoio (Tables 4 and 5). More broken branches, especially on Kinuyanagi, were observed on the trees coppiced at $1.0 \mathrm{~m}$ at Ballantrae. The diameter of stems browsed ranged from $2.7-7 \mathrm{~mm}$ with thicker stems browsed on Kinuyanagi than Tangoio or tagasaste (Tables 4 and 5).

Cattle preferred Kinuyanagi to Tangoio willow when first introduced to the sites. The weaner bulls and mixed-age cows at Ballantrae and the dairy heifers at Massey University spent 8, 49 and 14\%, respectively of their first 2 hours browsing Kinuyanagi as opposed to 6,34 and $14 \%$ of the time browsing Tangoio. Observation suggested that the browsing techniques of the younger cattle were learnt from other cattle.

\section{Discussion}

Further research is required to develop a method for estimating the quantity of edible
Table $\llbracket 2$ The percentage leaf and the nutritive value of forage (leaves plus stems $5 \mathrm{~mm}$ or less) from willow and poplar cultivars during summer.

\begin{tabular}{lcccrc}
\hline Cultivars & $\begin{array}{c}\text { Leaf } \\
(\%)\end{array}$ & $\begin{array}{c}\text { Protein } \\
(\mathrm{g} / \mathrm{kg})\end{array}$ & $\begin{array}{c}\mathrm{DMD}^{1} \\
(\mathrm{~g} / \mathrm{kg})\end{array}$ & $\begin{array}{c}\mathrm{ME} \\
(\mathrm{MJ} / \mathrm{kg})\end{array}$ & $\begin{array}{c}\mathrm{CT} \\
(\%)\end{array}$ \\
\hline Tangoio & 56.1 & $\begin{array}{c}\text { Willow } \\
117\end{array}$ & 579 & 8.7 & 4.18 \\
Matsudana & 66.1 & 154 & 672 & 10.2 & 1.79 \\
Moutere & 68.4 & 155 & 699 & 10.5 & 3.95 \\
Mean & 64.2 & 142 & 650 & 9.8 & 3.31 \\
& & Poplar & & & \\
Veronese & 66.4 & 179 & 698 & 10.4 & 0.98 \\
Louisa Avanza & 65.2 & 136 & 670 & 10.2 & 2.61 \\
Pakaraka & 72.3 & 165 & 687 & 10.3 & 0.93 \\
Selwyn & 61.6 & 150 & 676 & 10.2 & 1.92 \\
Toa & 67.0 & 134 & 607 & 8.9 & 0.60 \\
Argyle & 55.3 & 152 & 647 & 9.6 & 1.13 \\
Weraiti & 64.5 & 158 & 692 & 10.2 & 1.11 \\
Otahoua & 68.5 & 137 & 640 & 9.6 & 0.93 \\
Tasman & 60.4 & 128 & 694 & 10.0 & 2.36 \\
Mean & 65.2 & 149 & 668 & 9.9 & 1.40 \\
\hline
\end{tabular}

${ }^{1} \mathrm{DMD}$ - dry matter digestibility, ME - metabolisable energy, CT - total condensed tannins

Table $₫ 3$ Nutritive content of bark from willow (cV Tangoio) and poplar (cV Veronese) trees of differing ages during summer.

\begin{tabular}{lccccccc}
\hline Species/age & $\begin{array}{c}\text { Ash } \\
(\mathrm{g} / \mathrm{kg})\end{array}$ & $\begin{array}{c}\text { Protein } \\
(\mathrm{g} / \mathrm{kg})\end{array}$ & $\begin{array}{c}\mathrm{DMD}^{1} \\
(\mathrm{~g} / \mathrm{kg})\end{array}$ & $\begin{array}{c}\mathrm{ME} \\
(\mathrm{MJ} / \mathrm{kg})\end{array}$ & $\begin{array}{c}\mathrm{NDF} \\
(\mathrm{g} / \mathrm{kg})\end{array}$ & $\begin{array}{c}\mathrm{CHO} \\
(\%)\end{array}$ & $\begin{array}{c}\mathrm{CT} \\
(\%)\end{array}$ \\
\hline Tangoio & & & & & & & \\
5 yrs old & 89 & 52 & 662 & 10.2 & 367 & 15.4 & 9.2 \\
$\begin{array}{l}10 \text { yrs old } \\
\text { Mean }\end{array}$ & 107 & 44 & 599 & 9.1 & 485 & - & 7.1 \\
Veronese & 98 & 48 & 612 & 9.6 & 426 & - & 8.2 \\
5 yrs old & 67 & 33 & 577 & 9.2 & 511 & 16.2 & 2.2 \\
10 yrs old & 68 & 31 & 556 & 8.8 & 538 & - & 2.2 \\
Mean & 68 & 32 & 566 & 9.0 & 524 & - & 2.1 \\
SEM & 5.6 & 3.1 & 13.3 & 0.23 & 26.6 & - & 0.14 \\
\hline
\end{tabular}

${ }^{1} \mathrm{DMD}$ - dry matter digestibility, ME - metabolisable energy, CT - total condensed tannins, NDF - neutral detergent fibre, $\mathrm{CHO}$ - readily fermentable carbohydrate

Table 44 Tree forage yield and utilisation of Tangoio and Kinuyanagi willow by weaner bulls and mixed age cows at AgResearch Ballantrae.

\begin{tabular}{lcccc}
\hline & Tangoio & Kinuyanagi & SEM & $P$ \\
\hline Total DM (kg/tree) & 3.8 & 4.7 & 0.33 & 0.1015 \\
DM harvested $(\mathrm{kg} /$ tree $)$ & 0.7 & 1.4 & 0.1 & 0.0025 \\
\% green canopy grazed & 20 & 31 & 1.3 & 0.0037 \\
Grazing height $(\mathrm{m})$ & 1.9 & 2 & 0.04 & 0.0944 \\
Diameter browsed $(\mathrm{mm})$ & 3.8 & 7 & 0.44 & 0.0064 \\
\hline
\end{tabular}

Table $\llbracket \mathbf{5}$ Tree forage yield and utilisation of Tangoio and Kinuyanagi willow and tagasaste by dairy heifers at Massey University.

\begin{tabular}{lccccc}
\hline & Tangoio & Kinuyanagi & Tagasaste & SEM & $\mathrm{P}$ \\
\hline Total DM (kg/tree) & 2.4 & 4.2 & 5.4 & 0.57 & 0.0279 \\
DM harvested (kg/tree) & 0.9 & 2.4 & 1.7 & 0.26 & 0.0204 \\
\% green canopy grazed & 37 & 58 & 30 & 2.95 & 0.0012 \\
Grazing height (m) & 1.6 & 2.2 & 1.6 & 0.09 & 0.008 \\
Diameter browsed (mm) & 2.7 & 4.5 & 2.2 & 0.41 & 0.0195 \\
\hline
\end{tabular}


dry matter in a poplar or willow tree, but the data presented provide the first practical indication of the forage yield of poplar and willow trees. DBH would require the use of a curvilinear equation to predict forage yield if trees with a DBH greater than approximately $100 \mathrm{~mm}$ were felled for forage. The increase in forage yield was relatively slower than the increase in trunk cross-sectional area or DBH as trees aged. Johansson (1999) found that the relationship between DBH and leaves and twigs was curvilinear for poplars in dense forests in Sweden.

The simplified equation for the forage yield of branches of poplars and willows, $\mathrm{kg} \mathrm{DM}=0.04 \mathrm{BD}-$ 0.6 , has practical value for predicting the yield of forage in a willow or poplar branch. Oppong (1998) found that whether branch length or basal diameter was a better predictor of forage yield in willows depended on the cultivar. Grigg \& Mulligan (1999) found basal diameter was the best predictor of leaf mass in Acacia branches. The equation for poplar and willow branches was accurate up to a basal diameter of approximately $100 \mathrm{~mm}$ (predicted $3.0 \mathrm{~kg} \mathrm{DM}$ for $90 \mathrm{~mm}$ Tangoio cf. Table 1). It appears that the forage yield of branches, or small trees, with a basal diameter greater than $100 \mathrm{~mm}$ was best estimated by a curvilinear function. It is suggested that the pipe theory assumption that stem cross-sectional area is linearly related to leaf mass (Shinozaki et al. 1964) does not hold for poplars and willows with a trunk DBH or branch diameter greater than $100 \mathrm{~mm}$.

The nutritive values of the poplar and willow cultivars evaluated were within the range found by McCabe \& Barry (1988), Phipps (1989) and Oppong et al. (1996) for willows and by Phipps (1989) and Smith (1992) for poplars. Both poplar and willow forage were of superior nutritive value to typical hill pastures in dry summers. The nutritive value of bark, although low in protein, was sufficient to suggest that livestock strip bark from trees for its feed value and not just out of boredom.

The concentration of total condensed tannins was generally higher in willows than in poplars, but there were large differences between cultivars. Condensed tannins concentrations up to approximately $3.5 \%$ can improve protein utilisation by livestock (Barry \& McNabb 1999), but their effects on livestock feeding on poplar or willow forage have not been researched.

The preference of cattle for Kinuyanagi rather than Tangoio was in contrast to sheep being found to prefer Tangoio rather than Kinuyanagi (Oppong 1988). This contrast between sheep and cattle possibly related to the cattle preference being driven by the easier access to Kinuyanagi leaves and the sheep preference being driven by the lower condensed tannins concentration of Tangoio. Mixed-age cows were more effective browsers of the willows than young bulls or dairy heifers, probably as the result of learning from experience. Whichever way willows were coppiced, the branches on trees would need to be cut down for use as forage once they were more than $2 \mathrm{~m}$ above the ground.

\section{Conclusions}

Tangoio willow and Veronese poplar produce from 2$22 \mathrm{~kg} \mathrm{DM} /$ tree of edible forage between 5 and 10 years of age. The quantity of edible forage in poplar and willow branches with a basal diameter up to $100 \mathrm{~mm}$ can be estimated from the linear function presented. However, the non-destructive estimation of the forage yield of trees is more complex and requires more research. Willow and poplar trees provide forage for livestock of moderate nutritive value. Willow leaves, stems and bark have approximately double the condensed tannins concentrations of poplar. These results improve the ability to feed budget the poplar and willow edible forage available on a farm.

\section{ACKNOWLEDGEMENTS}

Wellington Regional Council for financial and logistical support, and Peter Cameron (WRC) for technical assistance with tree measurements. Phillip Budding (AgResearch) for technical assistance with the browsing experiment.

\section{REFERENCES}

Barry, T.N.; McNabb, W.C. 1999. The implications of condensed tannins on the nutritive value of temperate forages fed to ruminants. British Journal of Nutrition 81: 263-272.

Grigg, A.H.; Mulligan, D.R. 1999: Biometric relationships for estimating standing biomass, litterfall and litter accumulation of Acacia salicina on mined land in Central Queensland. Australian Journal of Botany 47: 807-816.

Johansson, T. 1999. Biomass equations for determining fractions of European aspen growing on abandoned farmland and some practical implications. Biomass and Bioenergy 17: 471-480.

Karlik, J.F.; Winer, A.M. 1999. Comparison of calculated and measured leaf masses of urban trees. Ecological Applications 9: 1168-1176.

McCabe, S.M.; Barry, T.N. 1988. Nutritive value of willow (Salix sp.) for sheep, goats and deer. Journal of Agricultural Science, Cambridge 111: 1-9.

Oppong, S.K. 1998. Growth, management and nutritive value of willow (Salix spp.) and other browse 
species in Manawatu, New Zealand. PhD thesis. Massey University.

Oppong, S.; Kemp, P.D.; Douglas, G.B.; Bulloch, B.T. 1996. Management of browse plants as drought fodder for sheep: a preliminary study. Proceedings of the New Zealand Grassland Association 58: 9397.

Phipps, K. 1989. Fodder crops: the poplar option. New Zealand Tree Grower 10: 6-7.

Shinozaki, K.K.; Yoda, K.; Hozumi, K.; Kira, T. 1964. A quantitative analysis of plant form - the pipe model theory. I. Basic analysis. Japanese Journal of Ecology 14: 97-105.
Smith, D.R. 1992. Changes in nutritive value of seven poplar clones over late summer and early autumn. Miscellaneous paper, AgResearch, Hastings, New Zealand.

Wall, A.J.; Mackay, A.D.; Kemp, P.D.; Gillingham, A.G.; Edwards, W.R.N. 1997. The impact of widely spaced soil conservation trees on hill pastoral systems. Proceedings of the New Zealand Grassland Association 59: 171-177.

Wilkinson A.G. 1999. Poplars and willows for soil erosion control in New Zealand. Biomass and Bioenergy 16: 263-274. 